\title{
BLOOMFIELD'S MILITARY COMPANY IN 1898
}

A few months ago there was discovered in the Archives Division of the Historical, Memorial and Art Department the "war bill" reproduced on another page and the following letter written by Hon. B. F. Carroll, then state senator:

Gov. L. M. Shaw,

$$
\begin{gathered}
\text { Bloomfield, Iowa, } \\
\text { May 30, } 1898 .
\end{gathered}
$$

Des Moines, Iowa.

'To His Excellency :-

Some of the young men of this county are urging me to write you asking that this county, Davis, be recognized in making up the next quota of voluntecrs. 'There is not a man who actually belonged in this county now in the service and they feel that we should be recognized. Can you not do something that will give an opportunity to organize a company here for active duty. Our private company tenders its service as will be seen by the enclosed circular.

Respt.

B. F. Carroll.

'The letter and "war bill" appearing to Mr. Stiles, superintendent of archives, to be of more than ordinary interest, he called them to the attention of the ANNaLs Division, and then they were shown to former Governor Carroll. He promptly wrote to Captain H. C. Moore of Bloomfield and asked him if he remembered that when the Spanish-American War broke out they offered their military company to Governor Shaw and tried to get it into service, and also asked for any other information concerning the matter that might be of interest. In reply to Governor Carroll's letter Mr. Moore replied as follows:

\section{Bloomfield, lowa,} April 2, 1931.

Hon. B. F. Carroll,

Des. Moines, Iowa.

Friend Frank:

This is in answer to your letter of March 31, asking about the Bloomfield Military Company which did not get into the Spanish-American War.

The company grew out of John Dunn Camp No. 70, Sons of Veterans of the Civil War. The camp was organized in 1896 or 1897. You will 


\section{WAR!WAR!!}

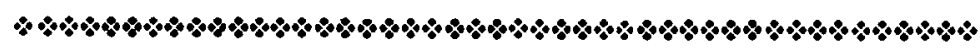

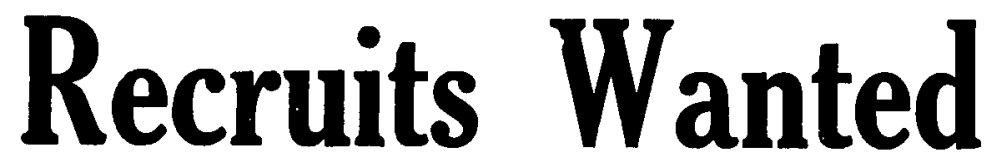

The Bloomfield Military Co.

Has Been Tendered Gov.

Shaw for

Active Service.

Recruits Will Report to Lieut. Cavanaugh at the Lighthouse, Bloomfield.

H. C. MOORE, Capt. 
notice that the company was an unlawful assembly until (ivvernor Shat issued his permit to you to organize a military company.

The company bought forty Springfield rifles. T'lie company kept. its oranazation until 1000. Its last appearance was on Decoration Day, 1900 .

The officess of the Bloomfield Military Company were Henry C. Moore, captain; Henry C. Young, first licutenant; and Daniel F. Cavanaugh, second lieutenant.

You need not return the enclosed papers.

Yours Truly,

H. C. Moore.

With Mr. Moore's letter he encloses a partial roster of the company, some explanations with reference thereto, and the following letters:

\section{State of Iowa \\ Adjutant General's Oftice \\ Des Moines}

Dr. H. C. Young,

November 26,1897 .

Bloomficld, Iowa.

Dear Sir:

Yours of the 25th instant is received. I herewith enclose the Military Code of Iowa, which will inform you concerning the organization of new companies and the expense of the same.

There is no vacancy in the Guard organization at this time.

There is no provision for mustering detachments and attaching them to other companies. The law provides for forty-eight infantry companies and four bands. Cavalry and artillery organizations are too expensive for lowa to indulge in with the limited appropriation we have. Your opportunity to get a place in the Guard will be when a compiny falls below the standard and is mustered out. 'This occurs quite frequently and is usually announced in the newspapers, so that all are made aceuainted with it.

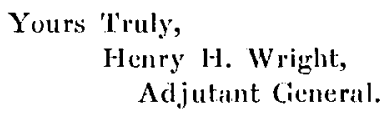

State of Lowa

Adjutant General's Office

Des Moines.

Dr. H. C. Young,

December 2, 1897.

Bloomfield, lowa.

My Dear Sir:

Yours of the 30th of November concerning the organization of a National Guard company in your city, is received. The Ottumwa com- 
pany is full. The recommendetion of General lincoln was two small towns join and organize a company by each place enlisting a portion of the company. 'There is no vacancy it present in either of the regiments and probably will not be before April or May. 'The way to proceed is as suggested in my former letter, watch and learn when a company is disbanded and then make application to organize a company. Yours Respectfully,

Henry H. Wright, Adjutant General.

Committec on Military $A$ ffairs, House of Representatives, U.S.

Col. S. A. Moore, Washington D. C.

Bloomfield, lowa.

December 14, 1897.

My Dear Colonel:

Your favor of the loth instant received. It would be impossible for your independent company to get arms from the Federal government. I think the proper way for you to do will he to apply to the state, and if they have any surplus arms it may be that you can get them. Otherwise you would be helpless.

I am very Sincerely Yours,

J. A. 'T. Hull,

H. C. Moore, Esq.,

Bloomfield, Iowa.

December 23, 1897.

Dear Sir:

There have been no permits, under Section 2200 of the Code, granted for the organization of independent military companies. Therc is no appropriation of equipment for such organizations. No permits have been granted for organizing inilitary companies, except for the regular National Guard service.

\section{State of Iow:, Adjutant Genéral's Office, \\ Des Moines.}

$$
\begin{gathered}
\text { Yours 'l'ruly, } \\
\text { Henry H. Wright, } \\
\text { Adjutant General. }
\end{gathered}
$$

State of Iowa, Executive Department,

Des Moines.

March 22, 1898.

Pẹmission is hẹreby granted Hon, B. F. Carroll, or any person 
assuciated with him, to organize and drill a military company composed of young men of Bloomfield and inmediate vicinity.

'I'lis permission is granted with the express understanding that it shall be without expense to the state.

L. M. Shaw.

\author{
House of Representatives U. S. \\ Washington, D. C.
}

\title{
Dear Carroll:
}

June 3, 1898.

I have again written Governer Shaw about the Bloomfield company. Inasmuch as the War Department acecpted four regiments from lowa on the first call instearl of three and with only sixty-four men to the company I understand that the old regiments must be filled to the miximum before a new regiment will be accepted.

$$
\begin{aligned}
& \text { Yours 'Truly, } \\
& \text { Jolin F. Lacey. }
\end{aligned}
$$

Hoin. B. F. Carroll.

$$
\begin{aligned}
& \text { House of Representatives U. S. } \\
& \text { Washington, D. C. }
\end{aligned}
$$

Cipt. H. C. Moore,

June 5,1898 . Dear Captain:

Your letter is at hand. I have already both wired and written to Governor Shaw in the interests of the Bloomfield company. Tlie War Department insists on filling the old regiments to the maximum first. They were aceepted as minimum regiments to prevent friction in mustering out the Guard officers and now the War Department seems to he determined that they must be filled up to the maximum in order to make them more effective.

The companies that were accepted in the first call were not accepted with a view to the distribution of troops equally through the states but simply because they were ready.

$$
\text { Yours 'Iru!y, }
$$

Joln F. Lacey.

State of lowil,

Exccutive Department,

Des Moines

Henry C. Noore,

June 14, 1898.

Bloomfield.

Dear Sir:

Yours of the 13th, with its inclosure, is at hand in the absence of the Governor, he having just left for Sioux City. I may, however, give the answer I know he would make if here. He has done nothing as yet 
toward the reorganization of the Nationat Guard, and he will do nothing in that direction for some time to come. The regimental organizations of our National Guard are now in the field, and will be recognized as such unless the unduc prolongation of the war shall seem to render necessary a reorganization of the Guard.

But your papers will remain on file for possible future reference.

Very Truly Yours,

$$
\begin{aligned}
& \text { William H. Fleming, } \\
& \text { Private Secretary. }
\end{aligned}
$$

\section{The Roster}

The names are taken from the original roll as it was signed at the time of organization of the company.

The original roll was on three separate sheets. I have lost one sheet. It is my recollection that there were about one hundred members, and a detachment at Milton of forty (40) who were ready to join us when we were called into United States service. - (H. C. M.)

$\begin{array}{lll}\text { H. C. Moore } & \text { W. B. Taylor } & \text { L. C. Bryant } \\ \text { H. C. Young } & \text { J. B. McIntire } & \text { J. R. Cannady } \\ \text { J. F. Appleton } & \text { Otto Schnorr } & \text { H. F. Curl } \\ \text { A. B. Welch } & \text { Willie Scoles } & \text { Ira. Walton } \\ \text { T. J. Hill } & \text { Sam T. Wallace } & \text { Leslie Eastlum } \\ \text { W. E. Dilliner } & \text { V. H. Brinker } & \text { Walter Johnson } \\ \text { C. E. Curl } & \text { Fred Allender } & \text { Ralph Hill } \\ \text { E. J. Griggs } & \text { W. A. Herman } & \text { J. F. Cronnable } \\ \text { J. C. Woods } & \text { J. Wray Young } & \text { D. F. Cavaniughl } \\ \text { E. B. Johnson } & \text { S. A. Reeves } & \text { Henry Shelton } \\ \text { C. A. Hazlewood } & \text { W. H. Black } & \text { E. M. Pugh } \\ \text { James A. Dunn } & \text { F. J. Meier } & \text { C. W. Graham } \\ \text { Louis Reinheimer } & \text { T. J. Mohler } & \text { J. G. Shelton } \\ \text { A. B. Caraway } & \text { H. W. Carlow } & \text { Asa Wilson } \\ \text { Albert Stein } & \text { Joc Wolfe } & \text { O. S. Shelton } \\ \text { Ed Williams } & \text { Leonard Goode } & \text { O. S. Snoddy } \\ \text { W. T. Dunlavy } & \text { W. R. Carroll } & \text { Barlow Allen } \\ \text { J. E. Howie } & \text { F. B. Childers } & \text { Claude C. Dabney } \\ \text { C. A. Eichelberger } & \text { Arthur Swearingen } & \text { Frank Battin } \\ \text { W. H. Wiseman } & \text { Clarles Baird } & \text { Freddic Lowenberg } \\ \text { E. M. Reeves } & \text { John Gore } & \\ \text { W. A. Mendenhall } & \text { W. W. Newton } & \end{array}$

The following was attached to the roster furnished by Captain H. C. Moore:

"The companies of the Forty-ninth, Fiftieth, Fifty-first and 
Fifty-second regiments of Iowa Volunteers, Spanish-American War, were mustered into the United States service with only sixty-five enlisted men per company. On the second call for volunteers the companies were ordered to be filled up to the maximum strength of one hundred men to a company.

"Sergeant Glenn Haynes, now Colonel Haynes, came to Bloomficld and cnlisted the following named persons:

"John E. Black, Oliver W. Boatman, Charles H. Chaffee, Alva Caswell, John M. Games, Edmond W. Greenleaf, Orlando Hummell, Jesse Kennedy, Charles D. Lane, Ira M. Prevo, T. Fuster Paris, Albert D. Penny, Elijah K. Pirtle, George H. Sax, Cyrus Turner and Henry Warrington. Most of the above were members of the company."

\section{BEGINNING OF OFFICIAL REGISTER}

Charles Aldrich, curator of the Historical Department, has unearthed a small pamphlet of but a few pages in paper cover printed in 1881, when Captain J. A. 'T. Hull was secretary of state, which gives a list of all the officers of the state and some other information. The pages are about three by three and a half inches. Mr. Aldrich believes it was the forerunner of the Official Register. The first Official Register was published in 1886. While Mr. Aldrich was elerk of the House many years ago when the state was young, he offered to gather the material without compensation if the legislature would appropriate a sum sufficient to print an official register. The legislature refused and the appropriation was never secured until 1886. Now the Official Regrister is recognized as one of the most valuable of state documents, and if it had been issued in that early day Mr. Aldrich believes would have preserved information now unobtainable almost. Four carly volumes of the Official Register, those of 1880 , 1887,1888 , and 1890 are now very rare and hard to obtain.Marshalltoton Times-Republican, November 1, 1906. (In the Newspaper Division of the Historical, Memorial and Art Department of Iowa.) 
Copyright of Annals of Iowa is the property of State of Iowa, by \& through the State Historical Society of Iowa and its content may not be copied or emailed to multiple sites or posted to a listserv without the copyright holder's express written permission. However, users may print, download, or email articles for individual use. 